speciil influence on the gencral state of health of the patient. The high temperature has often been observed to fall, both spontaneously and under the influence of quinine, while benzoate of soda has had no effect at all on it. 3. It seems to have some effect on the removal of the diphtheritie membrane, which may be derluced from the fact that, in six out of the nine eases which recovered, the meinbranes were cast off on the third day; in one ease on the fifth day; and, in three cases, they were visible from thirteen to twenty days. 4. The autlor does not think that any direct harm has been done by the use of benzonte of soda, although in some cases the patient had taken a consilerable quantity of it. In late years, all the remedies that have been recommended for diphtheria have been tried at St. Anne's Hospital. It lias resulted from these experiments that ice, elilorite of lime, and stimulants, have hitherto proved the most reliable means for the treatment of this terrible disease.-London Med. Record, Nov. 15, $18 \div 9$.

\title{
The Local Treatment of Putrid Expectoration.
}

Putrid expectoration is an accompaniment of various chronic affections of the lungs, and especially of bronchial dilatation. In the worst cases of this latter affection tlic patient is not only a nuisance to himself and his surroundings by the foul odour of his sputa, but the stagnation of the bronchial secretion on which its putridity depends is dangerous to himself in two ways-by the irritation and inflammation it is liable to cause at the seat of its occurrence, and by the infection of healthy portions of lung by inspiration of some of the putril matter. The uselessness of internal remcdics in these cases is wcll known, and many of them have been and no doubt still are opprobria medicina. Treatment by inlalation, especially of the terebinthinates, has been tricd, with a certain amount of success morc largely on the Continent than in this country, but the method adopterl has been faculty. A few drops of the drug have been poured on the surfice of hot water and inhaled for a few minutes two or three times a day, and a variety of eumbrous instruments have been suggested for this purpose. Two or three years agro, Dr. W. Roberts, of Manchester, described a simple portable "respirator inlualer," in the form of a metal box perforated in front and belind, and filled loosely with layers of tow on which the inhalation liquid was poured. This inhaler fits over the moutl, and is fixed by elastic bands over the ears like an ordinary respirator. The introduction of this instrument, although the medical profession as a body noy have failed to recognize it, was undoubtedly a step in advance. It showed the practicability of a continuous method of inhalation. This method has for some time been extensively tried witl an inhaler similar in principle to Dr. Roberts's, by Dr. H. Curschmann, late of Berlin, and now director of the Hamburg General Hospital, who has done much not only to popularize it, and to do away with objections to its use, but to prove its value in the most pasitive manner.

His respirator is figured in the Berliner Klinische Wochenschrift, No. 29, page 430 , and it is to be obtained from Duntzelt, 22 Schaaren-strasse, Berlin. It is made of vulcanite, and has a rim of soft Inrlia-rubber, wlere it touches the face, to insure close contact and prevent air entering the lungs except through the respirator itself. Dr. Curschmann generally eovers both nose and mouth, so that all air which the patient breathes is saturated with the vapour in the inbaler.

The substances used for inhalation, and which are poured on a sponge in the front of the cavity of the respirator, are all well-known drugs-pure oil of turpentine, carbolic acil, and thymol, either pure or dilutcd with from one to three parts alcohol, and creasotc. Dr. Cursehmann's application of them differs, low- 
ever, from what most practitioners are aceustomed to, in his using them either pure or, if clihted, but very slightly dihnted; and yet most careful examinations of the urine after the prolonged inlalation of oil of turpentine never revealed the least renal irritation; nor did the patients complain of any unpleasant symptoms, except occasionally a little oppression of the hear and hearlache. The sane is true of the use of undiluted carbolic acid previously liquefied by a gentle heat. If care be taken to wipe the edge of the inhaler frequently where it touches the face, and to anoint the face itself' with simple ointment, there is nolocul soreness; and $\mathrm{Dl}_{1}$. Cursehmann has never secn any initating effeet produced either on the inside of the mouth or on the larynx by the administration of the vapour of calbolic acid in so eoneentrated a form ; nor las any instance of so-called carbolic "intoxication" oceureel in lis practice. 'This statement refers to adults, as he has had scarcely any experience with children. He explains the harmlessness of the pure acid when inspired, first by the small amonnt of it which cvaporates and reaches the lungs at all ; and, sceondly, by the faret that the large part is, very soon after reaching the dilated bronehi or cavitics, expeetorated with their secretion, anel that the false membrane lining these cavities probslly offer's considerable resistance to its absorption iuto the system. Both carbolic acid and thymol eviporate much more freely in alcoholie solntion than when pure; and Dr. Cursehmanu has almost invariably used thymol in this form slone. Alcoholic solutions of carbolic acid are more apt to canse paroxysus of congh than the undihnted acid. More patients, howerer, olject to the nse of thymol than of carbolic acid; but the former is, no doubt, safer for childhern's use than the latter.

Creasote never recpuires clilution, and on this point we are able to eonfirm Dr. Curschmann's expericuec, but it is rery important to see that the druggist supplies a pure article. Corsdmann prefers crasote in cases where there is a tendency to hamoptysis; he finds that it not only has a styptic aetion and disinfecting properties as poweriul as those of carbolic acid, but that its rapour is sedative and allays rather than excites conyly. Inciulentally he mentions that he lias seen benefit result from ereasote inhalations in the hamoptysis of phthisis.

In illustration of the reilly wonkertinl ethects of the continuous inhalation method in putricl bronchitis, Ir. Cursehmann describes in detail two very severe cases of what in ordinary parlance would be ronghly called "phthisis." In the first ease the right lower lobe was aflected, there was dalness to the angle of the scapuli behind, witl lond bronchial breathinge, and abundant moist râles. The expectoration was very abmulant, and so fetid that it was difficult to stay near the paticut. Evening temperatine $38.6^{\circ} \mathrm{C}$; pulse 100. The patient, a mau of thirty-nine, hind fallen awiy very much during lis eigliteen months' illness, and weighed only fifty-seven kilogrammes, though of large build. He was treated with inhalations of pure earbolic aeid, at first for two or three hours at a time, and afterwards almost contimonsly. Witlin a few clays the sputa had almost lost their fetor; within a month tliey were absolntely orlourless. Simultaneously the temperature became normal, and the plyysieal signs of clulness, etc., as well as the patient's general condition, steadily improved. Before leaving the hospital, and under inhalation treatment alone, he hat gained nine and a half kilos, or about twenty pounds in weiglit. The second ease is quite as remarkable. A man of fifty-three, wholiad been ill some months with syuptoms of phthisis, was admitted under Dr. Curschnismn's care in Norember, 1878 , with dulness, bronchial breathing, and medium-sized moist râles over the lower half of the right lung posteriorly. At one point percussion was trmpanitie, and ausenltation revealed signs of a carity, which was proved to be such by tapping and drawing off some of its fetid contents. The patient expectorated about a litre of most intolerably putrid seeretion in twenty-four hours. His evening temperature was $39^{\circ} \mathrm{C}$., his pulse 112 , 
and he suffered from night-sweats. He was treated throughout with almost continuons inhalations, first of oil of turpentine, and then of pure carbolic acid. In three weeks the sputa were quite free from smell, fever and night-sweats had left him, and he only spat up about one-third of the amount on adnission. As in the first ease, there was an ultimate extraordinary disappearance of the abnornial physical signs, and the patient gained twenty pounds in weight during his scarcely six months' stay in the lospital. Except a little morphia for the cough just at the first, he took no merlieine internally-no hypopliosplites, no iron, no corlliver oil. In both cases the successful result ean be attribnted to nothing except to the antiseptic treatment_for sueh it is-by inhalation. We commend the study of the eomplete listory of these cases in the original to our readers, and urge on them a trial of the continuous methol of inhalation in suituble eases. We have been surprised to find even physicians with a large clicntèle of lung patients unaware even of the existence of so simple and valuable an instrument as Dr. W. Roberts's respirator inhaler.-Med. Times and Gazette, Nov. 15, 1879.

\section{Purulent Diaphragmatic Pleurisy.}

According to the remark of Laennee, if diaphragnatic plemrisy is one of the most common maladies, as the frequenec of arlhesions and talse membrancs observerl in this region after death attests, it is one of tlose which are most frequently unreeognized. In a work published in 1853, Dr. Nokl Guencau ne Messy has indicated signs which he believes render the diagnosis easier and more precise. They are repeated, and completed by some new observations, published in the Archives Generales de Médecine, July, 1879.

Besides the spontaneous pain and that which is evoked by manual pressure at the level of the base of the ehest, there are disturbanees of sensibility which appear to him to have a great value for diagnosis. The phrenic nerve undergou's a morbid irritation which throws light upon the seat of inflammation; it becones the seat of hyperasthesia, which may be determined at the lovel of the superficial expansion of the nerve in the epigastrie region, and especially at a point which he has ealled the "diapliragmatic button," because when it is pressci the patient complains instantly of a keen sensitiveness, sometimes of an excessive, unbearable pain, aecompanied by twinges which make him stant and groan. This point is found at the intersection of two lines, of which one is parallel to the external border of the sternum, and the other, perpendicular to this, follows and prolongs the border of the ribs.

The author knows only one disease of inflammatory eharacter in which, in a mueh lower degree it is true, this hyperesthesia of the phrenic nerve is observed. That is periearditis, and not only is it there less prononncerl, but often the seat of it is a little different, and the maximm of the abnormal sensibility, in many patients affected with periearditis, corresponds to the eosto-xiphoid angle.

At the same time that the terminal extremity of the phrenie nerve manifests this trouble of sensation, an exaggerated sensibility is determined between the two lower attachments of the sterno-cleido-mastoil muscle; the irritation is propagated in an ascending eourse along the trunk of the nerve; it is turned by a sort of reflex action upon the nerves which have a eonnection in origin with the phrenie, and provokes pains in the shoulder and in the subclavicular region.

A neuralgia and hyperasthesia of the last intercostal nerves not unfrequently aeeompany the hyperæsthesia of the phrenie nerve. Another habitual symptom, though not absolutely constant in eflusions upon the diaphragm, is the depression of the last rib eorresponding to the diseased sille. Pressed lown by the eollection of liquid, the diaphragm draws in this rib; and when the patient is seated it may 